\title{
Data integration and participatory process in developing integrated coastal zone management (ICZM) in the northern Baltic Sea
}

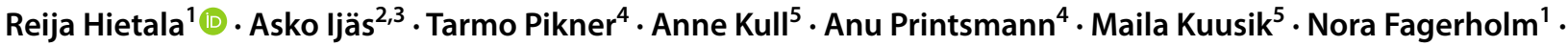 \\ Petteri Vihervaara ${ }^{6} \cdot$ Paulina Nordström ${ }^{1} \cdot$ Kirsi Kostamo $^{6}$
}

Received: 10 March 2020 / Revised: 8 July 2021 / Accepted: 9 July 2021 / Published online: 23 August 2021

(c) The Author(s) 2021

\begin{abstract}
The Maritime Spatial Planning (MSP) Directive was ratified (2014/89/EU) along the Strategy of the European Union (EU) on the Blue Economy to contribute to the effective management of maritime activities and resources and incorporate the principal elements of Integrated Coastal Zone Management (ICZM) (2002/413/EC) into planning at the land-sea interface. There is a need to develop the ICZM approach throughout Europe to realise the potential for both socio-economic and environmental targets set by the EU and national legislations. In this study, we co-developed different approaches for land-sea interactions in four case areas in Estonia and Finland based on the defined characteristics and key interests derived from local or regional challenges by integrating spatial data on human activities and ecology. Furthermore, four ICZM drafts were co-evaluated by stakeholders and the public using online map-based assessment tools (public participatory GIS). The ICZM approaches of the Estonian cases ranged from the diversification of land use to the enhancement of community-based entrepreneurship. The Finnish cases aimed to define the trends for sustainable marine and coastal tourism and introduce the ecosystem service concept in land use planning. During the project activities, we found that increased communication and exchange of local and regional views and values on the prevailing land-sea interactions were important for the entire process. Thereafter, the ICZM plans were applied to the MSP processes nationally, and they support the sustainable development of coastal areas in Estonia and Finland.
\end{abstract}

Keywords Coastal planning $\cdot$ Land-sea interaction $\cdot$ MSP $\cdot$ Public participation

\section{Introduction}

Coastal areas not only link terrestrial and marine ecosystem gradients but also are among the most populated areas worldwide (Small and Nicholls 2003). This situation creates

Reija Hietala

reija.hietala@utu.fi

1 Department of Geography and Geology, University of Turku, Vesilinnantie 5, 20014 Turku, Finland

2 Regional Council of Satakunta, 28101 Pori, Finland

3 Present Address: Brahea Centre, University of Turku, 20014 Turku, Finland

4 School of Humanities, Centre for Landscape and Culture, Tallinn University, 10120 Tallinn, Estonia

5 Estonian University of Life Sciences, 51006 Tartu, Estonia

6 Biodiversity Centre, Finnish Environment Institute, 00790 Helsinki, Finland challenges for both environmental conservation and sustainable development (Støttrup et al. 2017). Interests in the more active use of marine areas and resources increased substantially in the twenty-first century due to the limited availability of terrestrial space and resources (Costanza 1999; Stojanovic and Farmer 2013). In 2014, the EU reaffirmed that a coordinated approach to maritime affairs was to be enhanced by the development of the Blue Economy concept (EC 2014a). In addition, the Maritime Spatial Planning (MSP) Directive was ratified (2014/89/EU) to contribute to the effective management of maritime activities (EC 2014 b) and to incorporate the principal elements of integrated coastal zone management (ICZM) (Cisin-Sain 1993; Sorensen 1993; EC 2002; Ballinger et al. 2010; Kerr et al. 2016). Therefore, land-sea planning was incorporated as one integral part of the European MSP preparations (EC 2018a).

Preparation of ICZM plans can prove to be difficult when legislation and planning practices differ within, e.g., sea areas such as the Baltic Sea. In Estonia, the marine area 
belongs to and is planned by the state (Estonian Planning Act 2015), whereas in Finland, marine areas can be owned by the government, cities and municipalities or private actors (Finnish Land Use and Building Act 132/1999). The Finnish spatial planning system consists of a three-level plan hierarchy, where national-level policies and strategies are further implemented at the regional level by councils and at the local level by municipalities. The current Estonian spatial planning system consists of a two-level hierarchy: state-level and local-level planning have occurred since the administrative reform in the autumn 2017. Furthermore, the $2030+$ state-wide plan in Estonia addresses the elements of the marine context with international ports, core coastal areas of green infrastructure and potential areas of offshore wind parks, among others (Estonian Ministry of the Interior 2013).

Regarding MSP processes, it seems that Estonian MSP at the national level will not enact binding conditions to coastal areas, but functional interrelations are identified between the land and sea, and recommendations will be given for MSP implementation across different scales (Estonian Government 2017). The Estonian MSP will include 13 themes, e.g., the principles of balanced spatial development and measures required to ensure the preservation of heritage values and suitable areas for constructing energy, gas and communication networks. The published drafts and public discussions on the Estonian MSP process indicate the concerns of the Blue Economy regarding the locations of offshore wind parks and aquaculture sites (Tafon et al. 2018; Valner 2018). The institutional aim is to approve Estonian MSP plan at the end of 2021.

In Finland, the Land Use and Building Act was established in 2016 to meet the requirements of the MSP Directive. The councils of Finnish coastal regions prepared the MSP plan in three different parts. It was approved between November and December in 2020. Finnish MSP plan outlines, e.g., potential areas for underwater natural values, cultural values, energy production, fishing, aquaculture, shipping and tourism. In addition, the land-sea interactions were included in the planning process (Kaituri et al. 2017).

The main objective of this paper is to present how the ICZM concept can be taken into account considering the differences between the planning systems and in the European MSP processes. Furthermore, we intend to demonstrate the realisation of the ICZM planning process all the way from data collation and integration to finalising the plans after an active participatory process. Altogether, four pilot case studies were developed in Estonia and Finland to demonstrate the different approaches needed to enhance land-sea interactions for each case area. The case sites as well the main aims for each ICZM case were co-defined based on the integrated data on human activities and ecology and based on participatory processes involving residents and stakeholders at the municipal level in Estonia and at the regional level in Finland.

\section{Material and methods}

\section{Data integration}

The project area covered the former Läänemaa, Harju and Lääne-Viru counties in Estonia and the Southwest Finland and Satakunta regions in Finland. For the data integration of the project area, we collected the available relevant Estonian and Finnish spatial data on human activities and environmental features, which we estimated to be important for assessing the land-sea interaction. The data reflect coastal land use: summer cottages, residential areas, farming land, electricity grids, road networks and existing wind farms, as well as cultural heritage (e.g., valuable landscapes or shipwrecks), natural resources, topography and relevant biodiversity.

The criteria for data integrations were country-specifically designed to reflect the prevailing environmental and socio-economic conditions. In Estonia, the key aspects for integration were high environmental values, diverse coastalspecific economic activities, marginalisation within society, and cultural heritage across landscapes. For the Estonian data integration, overlay analyses were applied to incorporate values with MapInfo and ArcGIS (Külm et al. 2017). The respective key aspects of the integration of Finnish human and ecological data were valuable nature values (forests, mires, marine and coastal biodiversity) and human pressures, and their impacts were determined by ArcGIS zonation analysis, moving window analysis and cost distance analysis (Leikola et al. 2018).

During the two-year preparation of the ICZM cases, four to eight working group meetings in each case area were organised for stakeholders of the local or regional levels, based on the theories on power sharing (Tritter and McCallum 2006; Collins and Ison 2009) and the aspects of interactions and information flows between actors (Pomeroy and Douvere 2008). Therefore, the stakeholders with statutory positions (e.g., local government) and groups or organizations who affect the decisions (local enterprises, nature conservation organizations) and those who have knowledge about local conditions (civil society organisations, landowners) were involved in identifying interests and tensions regarding the preparation of the ICZM drafts. Public participatory GIS surveys for residents and visitors in the area were further utilised to identify relevant aspects of the cases: The online surveys were applied via an ArcGIS WebMap application for the Läänemaa case site and Maptionnaire for the other three sites, and the surveys were open for two to three months for each case. Features emphasized by the 
stakeholder cooperation and public participation of local respondents were reflected in the finalisation of four ICZM plans. The complete ICZM process was carried out along the co-designed activities in 2016-2018. The applicability of the ICZM plans was surveyed one year after the plans were finished in 2019 by assessing whether and how they had been incorporated in the national MSP processes (Fig. 1).

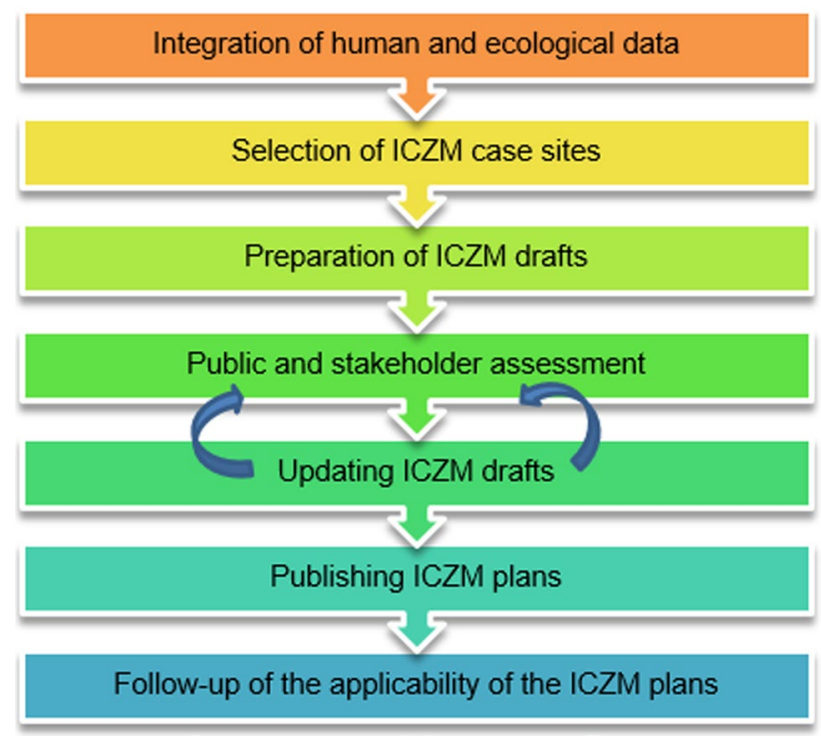

Fig. 1 Workflow of the ICZM process in Estonia and in Finland

\section{Case sites}

Two case sites in Estonia were selected based on the results of the thematic data integration of human activity and ecological data: the Läänemaa case area on the northwest coast and the Lääne-Viru case area on the north coast (Fig. 2). The Estonian ICZM cases were prepared by the researchers and planners of Tallinn University and Estonian University of Life Sciences in close cooperation with the coastal municipalities and stakeholders of the case sites.

In Finland, the Regional Council of Satakunta led the ICZM process. It was therefore crucial to state how the ICZM processes of the two cases in the region of Satakunta were linked to official regional planning to avoid confusion among the residents and stakeholders of the municipalities of the Satakunta region. The key themes of the two Finnish ICZM cases were to increase the understanding of the landsea interaction in Satakunta and thus to support the update of the existing regional land use plan and the preparation of the national-level MSP. The Finnish ICZM cases included sector-based tourism development in the coastal region of Satakunta and the ecosystem service approach for land use planning in the catchment of the River Kokemäenjoki (Fig. 2; Table 1). The integrated data on human activity and ecology were mainly utilised as the background information for the Finnish ICZM preparation. Overall, specific characteristics of the four ICZM case sites are shown in Table 1.
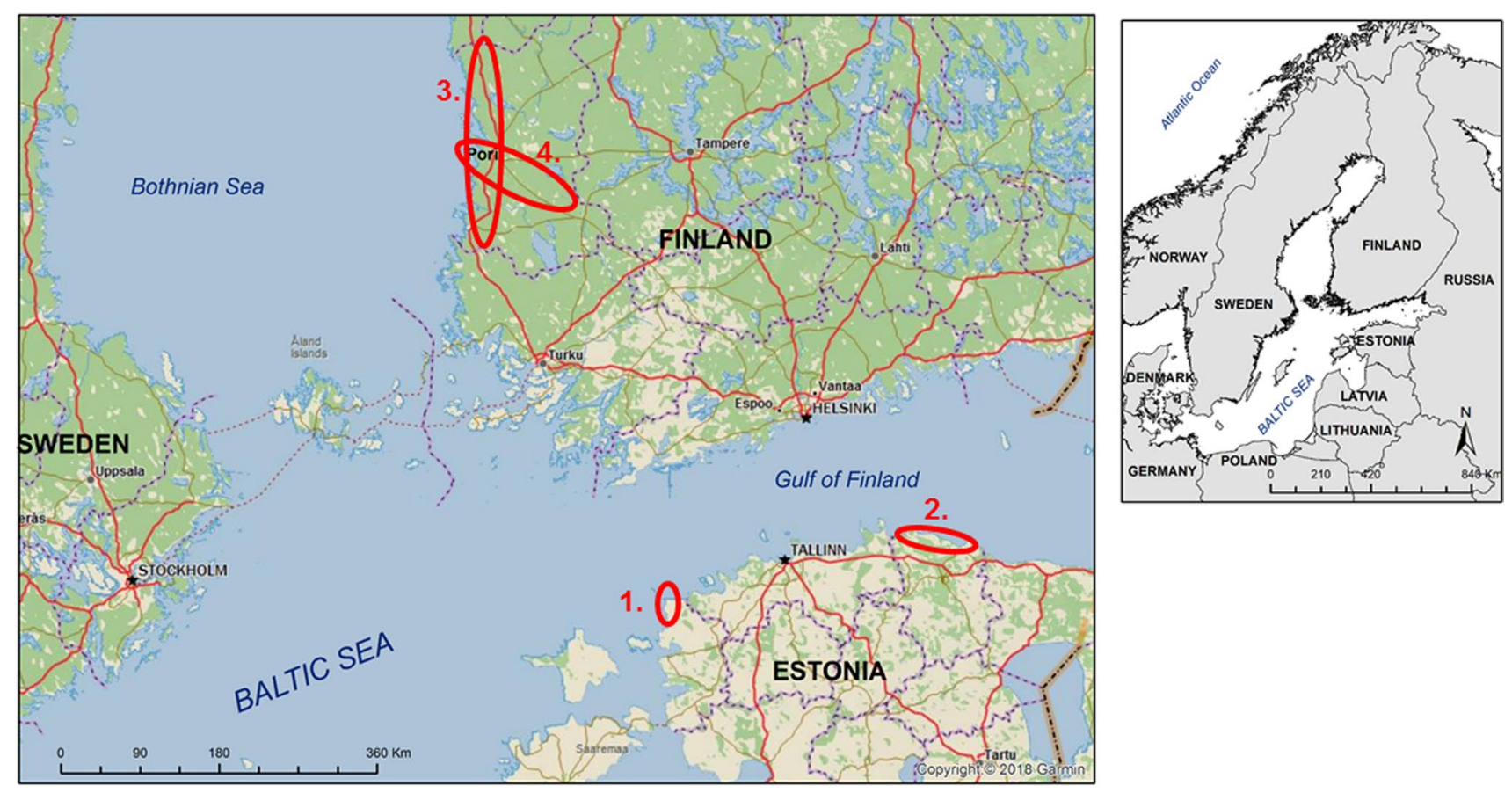

Fig. 2 The ICZM case sites are marked by a red line: 1. Läänemaa (Estonia); 2. Lääne-Viru (Estonia); 3. Coastal Satakunta (Finland) 4. The river valley of Kokemäenjoki (Finland) 
Table 1 The area, length of shorelines, population of four case areas and the defined main aims of the ICZM preparation

\begin{tabular}{|c|c|c|c|c|}
\hline \multirow[b]{2}{*}{ ICZM case } & \multicolumn{2}{|l|}{ ESTONIA } & \multicolumn{2}{|l|}{ FINLAND } \\
\hline & Läänemaa & Lääne-Viru & Satakunta coastline & $\begin{array}{l}\text { Subcatchment of the River } \\
\text { Kokemäenjoki }\end{array}$ \\
\hline Area of the site & $218 \mathrm{~km}^{2}$ & $457 \mathrm{~km}^{2}$ & $2,970 \mathrm{~km}^{2}$ & $2,860 \mathrm{~km}^{2}$ \\
\hline Length of shoreline & $48 \mathrm{~km}$ & $93 \mathrm{~km}$ & $140 \mathrm{~km}$ & $\begin{array}{l}80 \mathrm{~km} \text { (the length of the river } \\
\text { within Satakunta) }\end{array}$ \\
\hline Population (2017) & 400 & 1,500 & 72,900 & 118,800 \\
\hline $\begin{array}{l}\text { Key themes of the ICZM } \\
\text { case }\end{array}$ & $\begin{array}{l}\text { Support the diversifica- } \\
\text { tion of land use, enable } \\
\text { sustainable land use } \\
\text { development }\end{array}$ & $\begin{array}{l}\text { Enhance sustainable recrea- } \\
\text { tion, mobility, entrepre- } \\
\text { neurship }\end{array}$ & $\begin{array}{l}\text { Enhance sustainable } \\
\text { marine and coastal } \\
\text { tourism }\end{array}$ & $\begin{array}{l}\text { Introduce the ecosystem } \\
\text { service-based approach in } \\
\text { land use planning }\end{array}$ \\
\hline
\end{tabular}

In all four case areas in Estonia and Finland in 2016-2018, the local residents and other stakeholders were informed via the public media and networking events about the preparation of the ICZM plans. People were also informed how to participate in the preparation and evaluation of the first ICZM drafts so that the plans could be finalised before the end of the project.

\section{Results}

\section{Estonian ICZM plans at the municipal level}

When spatial data covering the Läänemaa case area were collected and analysed, including municipality plans and environmental, cultural, demographic and historical data, the two most prominent problems were defined as the aging population and the lack of working opportunities. On the other hand, seasonality in the recreation sector was also evident since Läänemaa is a popular area for summer housing (Väinameri Project 2005; Palginõmm and Veersalu 2013).

Methodologically, the Läänemaa case area was divided into coastal and marine zones (Fig. 3). The coastal zone (HELCOM 1994) incorporates coastal waters to allow for a closer integration of land and sea activities such as residential and recreational activities, ports and industries. During the preparation of the ICZM, possible conflicts among sectors were identified, and restrictions and suggestions for coastal development were determined to enhance the selected activities specific to each site while still providing possibilities for the development of other sectors as well (Kull et al. 2018). Activities at sea were established based on the Estonian MSP methodology (Hendrikson and Ko OÜ 2018).

The northern coast of Estonia is different from the west and northwest coasts - instead of long sandy beaches and coastal meadows, there are till shores and erratic boulders. Lahemaa National Park covers the major part of the LääneViru ICZM case area, which enacts as the framework for the nature protection and maintenance of cultural heritage as well as offers a wide range of public recreational services. Cultural heritage is characterised by the traditional settlements of coastal villages. Large areas near the shoreline are, however, underdeveloped due to the historical shore use restrictions from the Soviet period (Printsmann and Pikner 2019). In Lääne-Viru, the land-sea interaction challenges were discussed with stakeholders based on the maritime vision of Lääne-Viru County and focused on three main sectors: the development of maritime transport, the viability of coastal communities and the sustainable use of natural resources. The traditional land use zone planning approach was replaced with more focused features on recreation, community and location-specific based entrepreneurship (e.g., hiking trails, small-craft harbours), with general and location-specific guidelines for each provided in the ICZM plan (Kuusik et al. 2018) (Fig. 4).

The ICZM preparation processes in Estonia facilitated finding common ground across a range of sectors and stakeholders. The collaborative and participatory approach that included public location-based survey analysis and meetings conducted with local entrepreneurs and community members was proven to be valuable, and as a result, local knowledge was taken into account in the final ICZM plans. Thus, even though concrete maps were produced during the process, increased communication and exchange of views and values were seen as the most important results of the Estonian ICZM process.

\section{ICZM plans of the coastal regional and river catchment level in Finland}

The Satakunta coastal region consists of a narrow and rugged archipelago and a low-lying coastal zone (Fig. 1). Over $60 \%$ of the shoreline has already been used for either residential or industrial use (Laurila and Kalliola 2008). To protect coastal waters and the archipelago, several marine and coastal protection areas have been established based on the Finnish Nature Conservation Act (1096/1996) 
or the Habitats Directive (92/43/EEC). However, marine and coastal tourism is one of the economic sectors where growth is sought in the region (Regional Council of Satakunta 2017). Therefore, four key themes i.e., environmental protection, spatial characteristics of tourism, the enhancement of sustainable tourism, and increasing environmental knowledge and awareness were defined to link the ICZM approach to sustainable tourism development (UNEP and UNWTO 2005; UNEP 2009). The project planners of the Regional Council of Satakunta identified how current and proposed human activities affect the coastal region based on data from meetings with regional stakeholders. In addition, an online participatory GIS survey was available to the public that could be used by residents and visitors to pinpoint relevant recreational sites and describe their views and values. Tourism development linked the management of cultural heritage (e.g., historical road network) and defined nature-based destinations to the development of the regional structure of marine and coastal tourism (Ijäs 2018a) (Fig. 5).

The objective of the second Finnish ICZM case was to introduce the ecosystem service concept (e.g., Slocombe 1993; CBD 2004; Forst 2009) for integrated land use management in the catchment of the River Kokemäenjoki, which discharges into the Baltic Sea. The plains for the River Kokemäenjoki are utilised by agriculture regions with residential areas, whereas forests and marshes feature the upper parts of the river valley where the soil is less suitable for agriculture (Louekari 2012). Considering ecosystem services in planning allows combining the natural and societal values in that it provides knowledge on natural resources important to people. This diversifies and clarifies the value of nature: nature has intrinsic value on its own, but adding value based on ecosystem services may enable valuation of nature also in cases where monetary comparisons are involved (EC 2018b).

In Finland, ecosystem services are not fully embedded in national-, regional- or local-level planning processes (Niemelä et al. 2010; Rinne and Primmer 2016; Similä et al. 2017; Tammi et al. 2017). However, both ICZM and MSP processes emphasise the need to apply ecosystem-based management in marine and coastal planning (Soininen 2015; Inàcio et al. 2018). In the River Kokemäenjoki ICZM case, the applicability of the ecosystem service concept was discussed with regional stakeholders to define different values of landscape components (artificial surfaces, agricultural areas, forests and semi-natural areas, water bodies and natural environments) (Fig. 6). Thereafter, the study of the nationally notable ecosystem services in Finland according to Mononen et al. (2015) was utilised. The benefits of the defined ecosystem services of the River Kokemäenjoki planning area were divided into three categories according to their scale, and the most relevant landscape components for each defined ecosystem service were identified (Table 2) (Ijäs 2018b).

The regional expert assessments highlighted the fact that an ecosystem approach would complement land use planning, although the existing legislation, i.e., the Finnish Land Use and Building Act (1999), was then seen as satisfactory. The online location-based survey was also utilised for public assessment to define the local and regional relevance of the landscape components, while the ICZM plan did not aim to provide a comprehensive view on ecosystem services or their management (Ijäs 2018b). Overall, we see that an approach that incorporates ecosystem services into land or sea use planning might provide valuable links between nature and society.

\section{The participatory processes in developing the ICZM plans}

The respondents of the online surveys commented and suggested modifications or improvements to the ICZM drafts or identified interesting places in the area or new activities with total 427 responses on the online maps (Table 3). Responses attained by public location-based online surveys and the comments gained from the interest group meetings were utilised for each case to finalise the ICZM plans at the end of 2018.

Although the key themes and tools among the place-based online surveys varied, the public feedback included mainly similar concerns on the state of the coastal environment, e.g., regarding the enhancement of good water quality and tidiness of the environment, as well as suggestions for developing new activities in the case area and the development of infrastructure (Table 3). The respondents also pointed out important sites with cultural values and expressed views on values such as quietness, pure nature or otherwise pleasant landscapes.

\section{Discussion}

\section{Preparation of the ICZM cases}

Collating and integrating multiple land-sea datasets with ecological and socio-economic relevance requires close cooperation among researchers and planners. Existing data, e.g., ecological conditions and potential impact mechanisms across the land-sea interface, need to be translated into meaningful interpretations of how proposed human activities affect coastal ecosystems and how these impacts can be mitigated with planning. This kind of analysis requires not only spatial data on the area but also a thorough combination of multiple datasets from various sources and various fields of science. This phenomenon has also been previously 


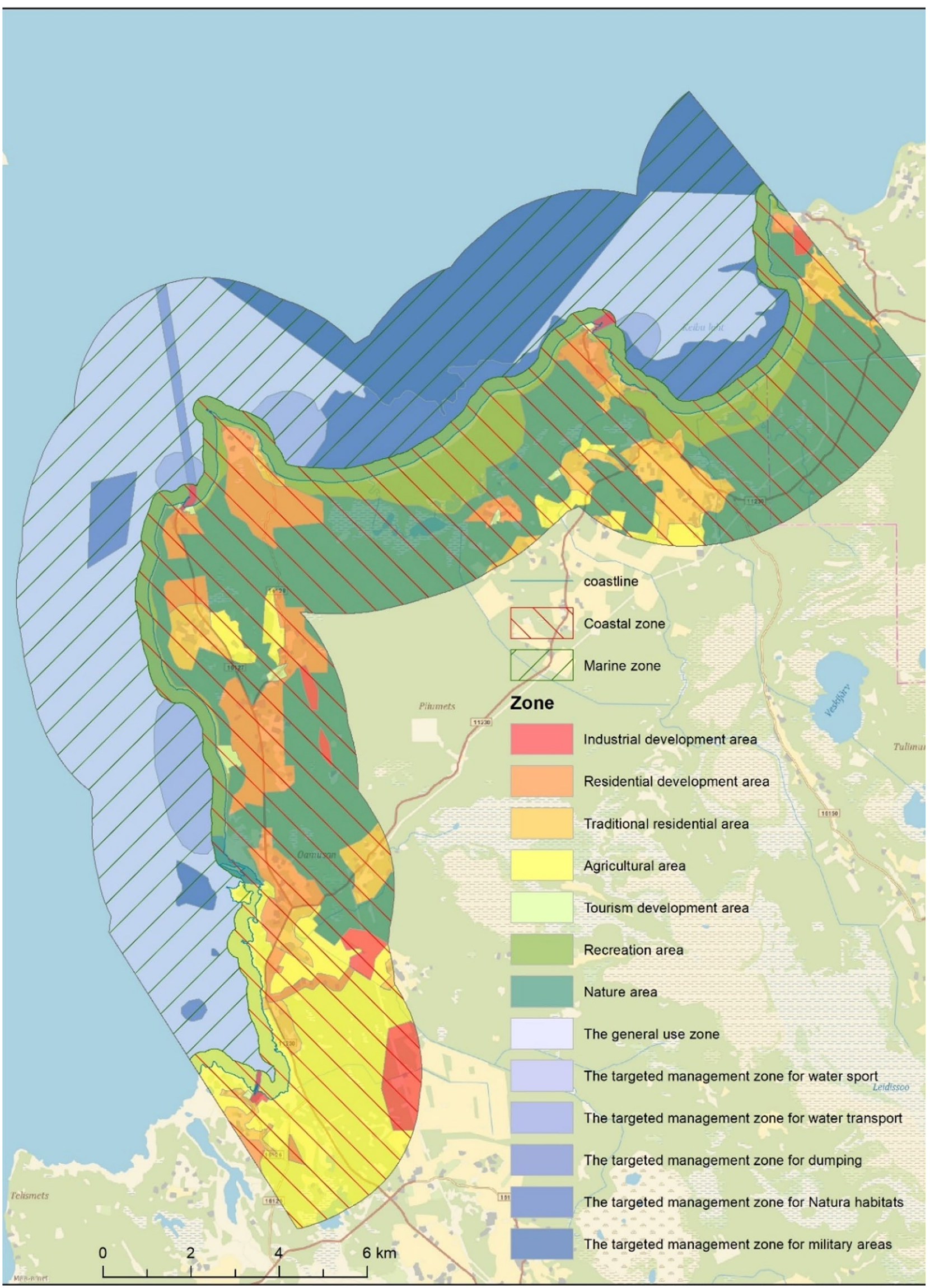


4Fig. 3 The extent of Läänemaa land use designation zones developed as a part of the ICZM plan on the northwestern coast of Estonia (Kull et al. 2018)

considered one of the challenges to the preparation of MSP by Schaefer and Barale (2011).

Furthermore, the approaches of the ICZM have to be defined early in the process. In the cases in Estonia, the maintenance of the socio-economic structures in coastal areas that resulted in income from taxpayers and enterprises to employ local residents and uphold local services for visitors and summer residents were seen as one key goal for the plans. Sustainability was especially important in the northwestern coastal area of Estonia in Läänemaa, where the idea of the ICZM preparation was based on developing land use zoning to reduce conflicts caused by contradictory land use (e.g., nature conservation vs. recreational and industrial or agricultural development, local people $v s$. visitors). During the ICZM process for Läänemaa, it was reported that one solution was to concentrate seasonal tourism in certain areas, e.g., by developing infrastructure of holiday villages to leave other areas for nature conservation purposes. This example illustrates the capability of the processes to identify and solve conflicts among the different stakeholders.

An administrative reform was prepared and implemented to terminate the Estonian county governments in the autumn 2017 (Tafon et al. 2018; Valner 2018). As a result, it was both interesting and challenging to moderate the stakeholders of Estonian municipalities to rethink the coastal aspects within general land use plans while the state was responsible for the planning of the sea areas. The governance and planning level of coastal areas should be clarified during all planning processes to provide possibilities for coherent economic growth and environmental protection at the landsea interface.

In fact, many questions were identified during the Estonian and Finnish ICZM case preparations, which could not be solved by utilising spatial planning alone, e.g., values linked to the coastal fishery or the planning and impacts of small harbours in Lääne-Viru or the development of marine and coastal tourist attractions in the Satakunta region. Although the approaches of the Finnish ICZM cases were determined to be more strategic than practical approaches, Finnish cases were also targeted to promote explicit collaboration between spatial planners and stakeholders. Since solving most of the issues would require significant collaboration not only between authorities but also among authorities, other stakeholders, residents and visitors of the coastal zone, it is important to recognise that the participatory process can improve the overall governance of coastal areas. This result means that the ICZM process with the involved land-sea interactions addresses several dimensions of marine and coastal planning (Papageorgiou 2016) and pushes us to rethink the multiple roles of culture in sustaining coastal landscapes (Printsmann and Pikner 2019).

At the point of the realisation of the project, the MSP process in Finland could not define the ecosystem-based approach or the role of the ecosystem services within it. This case study facilitated the discussion (in 2016-2018) and provided background for a more concise approach to the ecosystem services in ecosystem-based MSP approach. According to the EU MSP Directive, MSP follows the ecosystem-based approach, which means that MSP shall be based on the best available scientific knowledge about the ecosystem and its dynamics (EC 2018b). Defining the scale and distribution of ecosystem services is one possibility to address competing interests in planning especially in sectors which are dependent on certain services. Provisioning services can provide food, raw materials and energy for the society, thus providing opportunities for local people and communities as well as businesses to thrive. Regulating and maintenance services are linked to the quality of the environment, so they are important for sectors like aquaculture, agriculture, forestry and tourism. Cultural services provide recreational and spiritual opportunities for people but are also linked to economic activities. Adding the ecosystem services concept into the participatory process will thus enable more profound assessment on the importance of nature to the society than if the discussions were based only on the intrinsic value of the environment. It can thus increase common understanding of values and interests and enable consolidation of originally competing sectors.

Overall, we experienced that the vague status of the ICZM within the MSP processes and the spatial planning systems meant that some Estonian and Finnish institutions did not see the direct benefits of the ICZM initiative. On the other hand, the undefined institutional status of the ICZM made it possible to test different thematic approaches and scales based on local or regional case-specific socio-economic and environmental conditions. However, the lack of the different ICZM approaches makes it difficult to fulfil the requirements of the EU's legislation on planning coherence at the land-sea interface; therefore, examples of processes are necessary to incorporate marine and terrestrial data during planning processes.

\section{Importance of the participatory process during ICZM}

Schernewski et al. (2018: p. 546) pointed out the relationship between the planning process of coastal protection and public participation in the southern Baltic Sea: "Therefore, mere local public participation is not appropriate. To avoid a disintegration between local and regional interests, the involvement of regional stakeholders is required. Further, a commitment throughout the entire process until implementation, 
Fig. 4 The ICZM plan for the Lääne-Viru case area in northern Estonia (Kuusik et al. 2018)

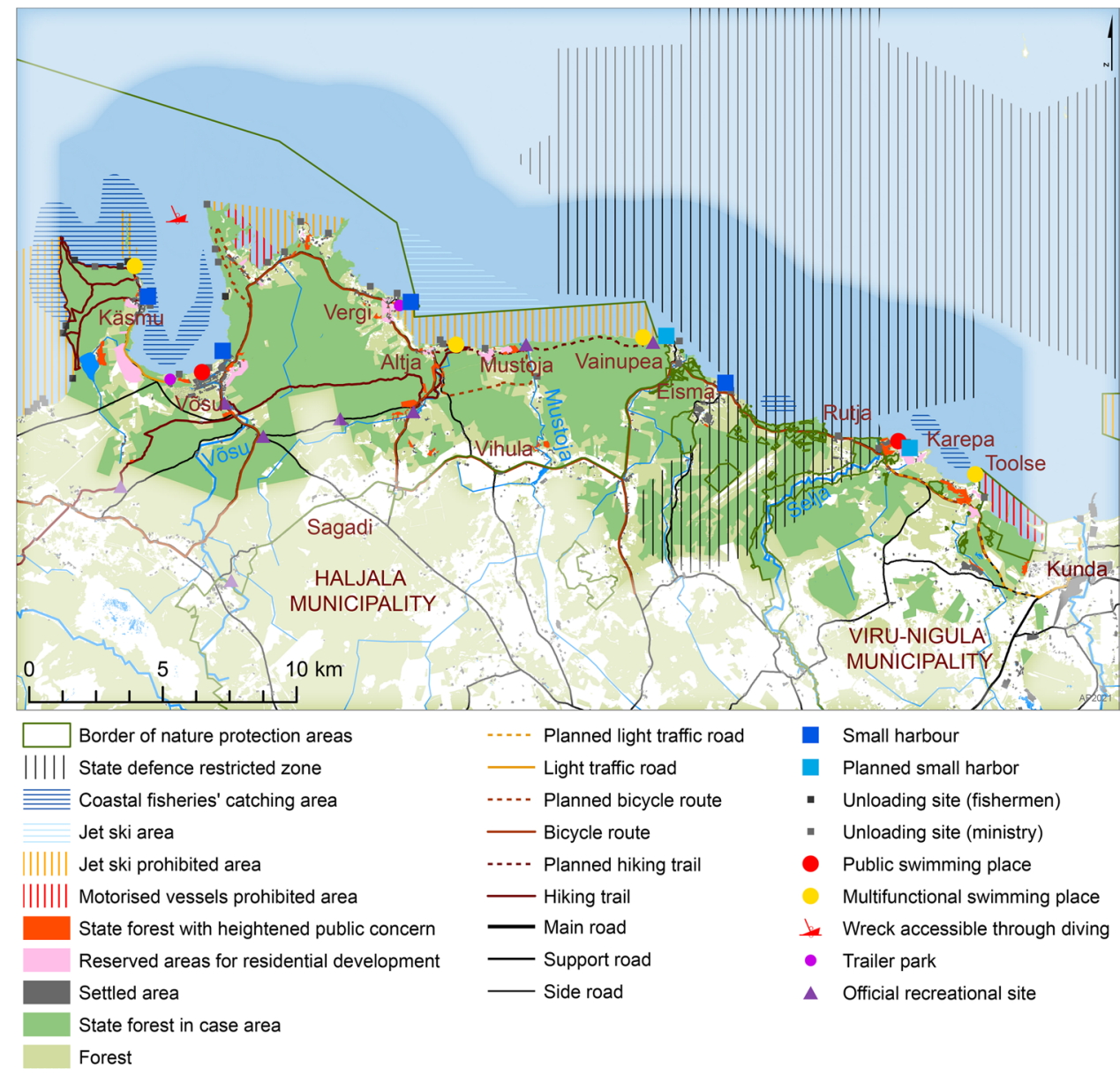

monitoring and success evaluation is necessary". Similar results were obtained during our entire ICZM plan process, where the preliminary plans that were prepared based on data integration were amended after the results of the participatory process were obtained. Especially in the two Finnish cases, where the regional-level planning authority actively involved it's already established network of local municipalities as well as regional experts on coastal tourism and environmental management, the advantages of the participatory process were evident when the different stages of the ICZM plans were compared. Similar benefits were discovered during the Estonian ICZM processes, where communication between planning authorities and stakeholders resulted in the modification of plans.

Støttrup et al. (2019) recently improved the application of the systems approach to promote spatial ICZM implementation, and they paid special attention to the maintenance of stakeholder engagement so that stakeholders could discover how their input contributed to the actual spatial plans. The possibilities for follow-up actions will be the most useful to avoid fatigue from participating in public assessment queries or events, as stated by Gillgren et al. (2018). It is evident that activating stakeholders in future ICZM planning processes requires active communication of the current results between planning authorities and stakeholders as an integral part of the entire process. Thus, the development of a communication plan that includes the correct temporal scale and relevant activities is a prerequisite for a successful ICZM process.

The participatory process also provided support for the analysis of environmental questions, e.g., by identifying the environmental values important to stakeholders. However, we argue that only the values that are understandable or known by stakeholders can be mapped and identified using participatory methods, i.e., complex environmental processes or important habitats that are not well known by stakeholders will most likely not be recognised during participatory processes. This said, participatory mapping has much higher potential in defining the socio-cultural and economic features of the case areas because these features are directly linked to the everyday activities and preferences of the respondents. 
Fig. 5 The ICZM plan for the Satakunta coastal zone in Finland focusing on the development of the regional structure of coastal and marine tourism (Ijäs 2018a)

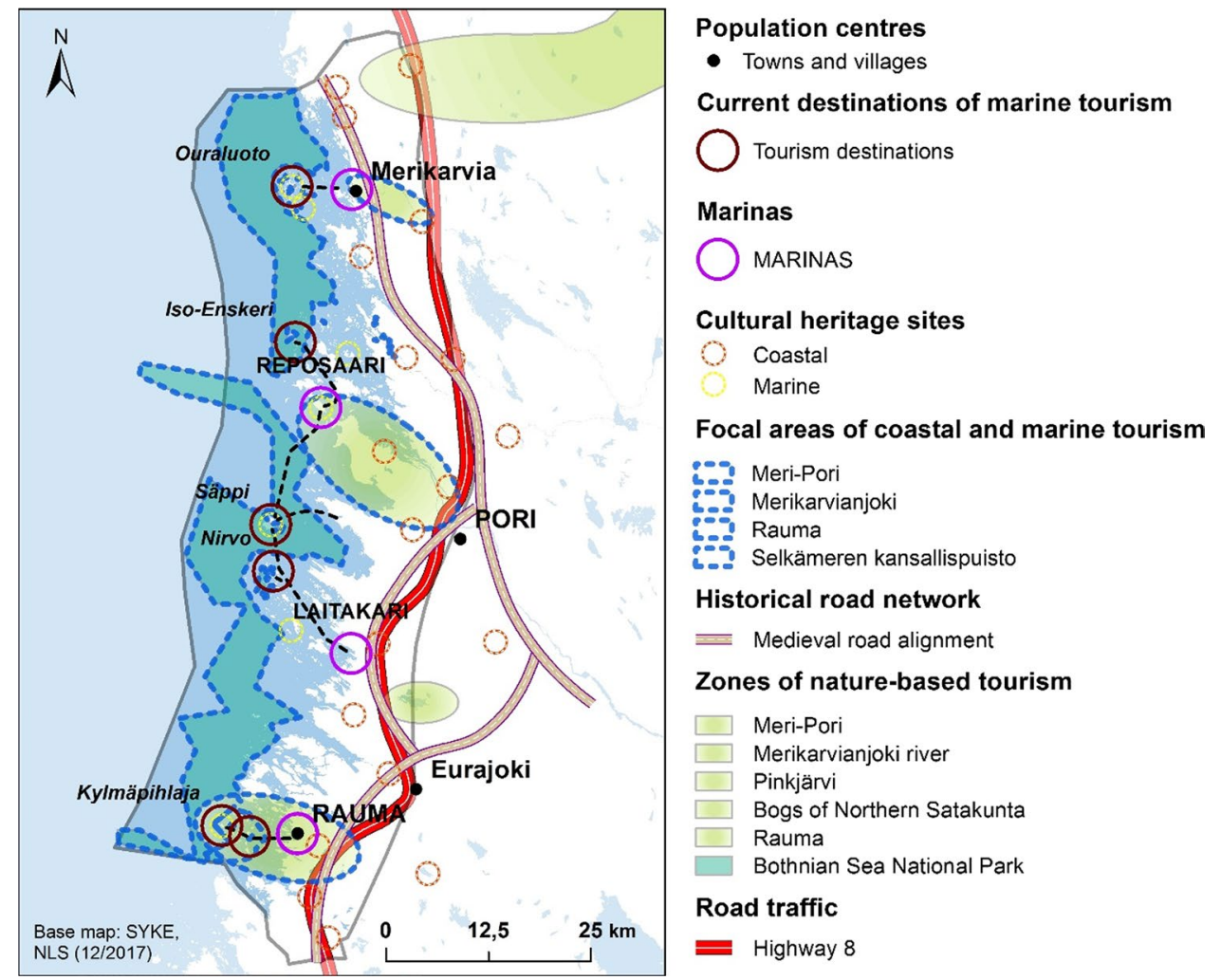

\section{The application of Estonian and Finnish ICZM plans in official planning processes}

Consultations in the end of 2019 with the Estonian MSP coordinators indicated that the finalised Estonian ICZM case plans were utilised as an input in the national MSP process to address land-sea interactions and highlight the regional specificity of regional development strategies (personal comm. Lepland T Ministry of Finance, Metspalu P Hendrikson and Ko OÜ, 18 December 2019). At the moment, consideration is being given to how the ICZM cases can be included in the implementation of the national MSP plan in Estonia. At the municipal level, Estonian ICZM plans are currently utilised by spatial planners as thematic background material for working on themes related to coastal accessibility and coastal tourism (personal comm. Kalberg H and Vahtra J Artes Terrae OÜ, 18 December 2019). However, at the first phase of the formulation of the coastal municipal general plans, the authorities of the municipalities of Lääne-Nigula in Läänemaa and Haljala in Lääne-Viru focused on the development of residential areas, and considerations of the land-sea interactions were included in the second phase of the general plan process. At the local level, the utilisation of the case ICZM plans was still affected by the Estonian administrative reform in the autumn 2017 due to the major staff changes in the municipalities - the recently recruited planners in the field are less familiar with the recent project processes and legally unbound local plans. The ICZM plans provide an ample set of integrated knowledge and links to experts to support local-level planning.

In Finland, the ICZM plan of the Satakunta coastal region was applied as background knowledge to characterise marine and coastal tourism for the national MSP plan in the Archipelago Sea and the southern Bothnian Sea in 2019 (Nummela et al. 2019), and for defining the potential areas for tourism and recreational activities of Satakunta in the final MSP plan 2030. The ICZM case on the River Kokemäenjoki catchment within the Satakunta region was utilised in 2019 to update the Satakunta regional land use plan, especially on environmental values (Vilen 2019).

Based on our experience, it can be shown that the results of the ICZM process are utilised at different levels of land use planning from the local to national level and beyond. The usefulness of the process can range all the way from simply utilising the integrated data collated during the ICZM process to identifying more complex relationships among different socio-economic and environmental processes by making the local and regional stakeholders communicate with each other or with authorities. 
Fig. 6 The ICZM case area of the River Kokemäenjoki valley in the Satakunta region in Finland was divided into five landscape components: artificial surfaces (built areas); agricultural environments; forests and semi-natural areas and water bodies (Ijäs 2018b)

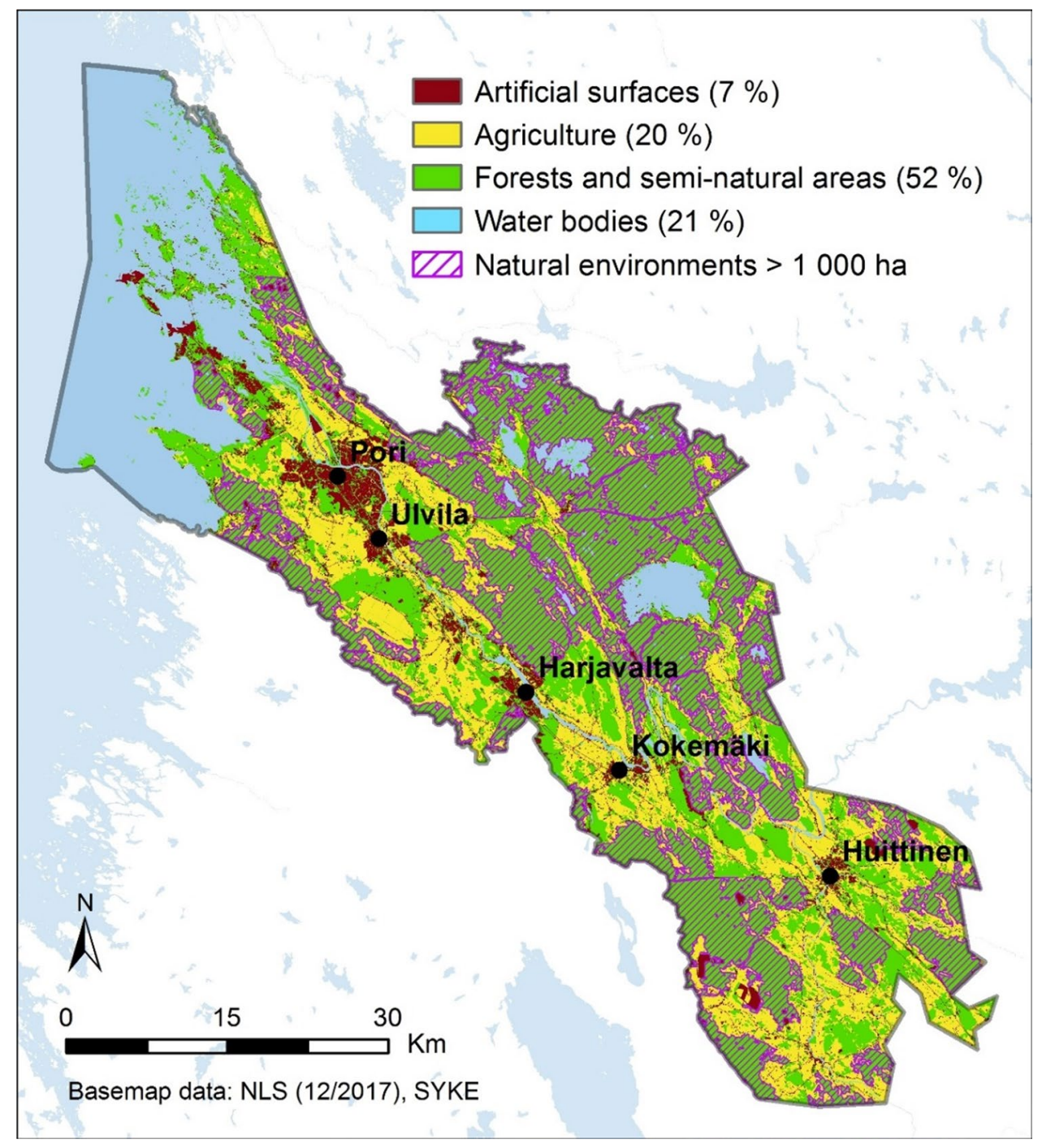

\section{Conclusions}

ICZM emphasises the need for integrated management of coastal features and resources (Earth Summit 1992; EC 2002). After the ICZM concept was merged into MSP in Europe in 2014, the ICZM concept was not widely utilised in Europe even though the MSP Directive states the possibility of complementing MSP with ICZM (Soininen 2015). We produced four ICZM case plans consisting of different key themes and scales, providing possibilities to enhance the currently ongoing MSP processes and support spatial planning at municipal or regional levels. Although the ICZM concept was identical in all cases, local environmental and socio-economic conditions resulted in differences in the ICZM plan outcome, which clearly demonstrates the strengths of the concept: plans should always reflect the prevailing socio-economic and environmental conditions of the studied area.
The utilisations of the produced ICZM plans were surveyed one year after their finalisation to discover whether the outcomes of the process were applied for municipal- or regional-level planning or for the national MSP processes. It was discovered that the ICZM plans with integrated data and participatory observations had been utilised at different planning levels in both countries. This finding implies that the role of ICZM can be seen as a site-specific collaborative framework that includes a broad bottom-up participatory approach to support sectoral policy preparation and coastal planning. This result is important, especially when planning sea and land areas governed by different planning authorities, which may result in a lack of knowledge and policy transfer at the interface. It can thus be stated that the role of ICZM could be developed as a concept for integrating policy needs in a complex geographic interface so that the full potential for socio-economic growth and environmental protection can be achieved. 
Table 2 Defined ecosystem services in the River Kokemäenjoki planning area with their scale (+immediate benefits at the local scale; ++ sustains the basic functions of the ecosystem but does not provide concrete benefits at the regional scale; +++ sustains the basic functions of the biosphere but benefits at the national or international level cannot be measured) and landscape components (Ijäs 2018b)

\begin{tabular}{|c|c|c|c|c|}
\hline & & Ecosystem services & Scale & Landscape component \\
\hline \multirow{9}{*}{$\begin{array}{l}\text { Provisio } \\
\text { ning } \\
\text { services }\end{array}$} & \multirow{6}{*}{ Food } & Berries and mushrooms & + & Forest \\
\hline & & Game & + & Forest \\
\hline & & Fish and crayfish & + & Water \\
\hline & & Crops & + & Agriculture \\
\hline & & Animal production & + & Agriculture \\
\hline & & Clean water & + & Water \\
\hline & \multirow{2}{*}{ Raw materials } & Wood & + & Forest \\
\hline & & Genetic resources & +++ & Forest/agriculture/water \\
\hline & Energy & Bioenergy & + & Forest/agriculture \\
\hline \multirow{12}{*}{$\begin{array}{l}\text { Regulati } \\
\text { on and } \\
\text { maintena } \\
\text { nce } \\
\text { services }\end{array}$} & \multirow{5}{*}{$\begin{array}{l}\text { Purification, } \\
\text { sequestration } \\
\text { and storage of } \\
\text { harmful } \\
\text { substances }\end{array}$} & $\begin{array}{l}\text { Regulation of waste and } \\
\text { toxins }\end{array}$ & ++ & Agriculture/forest \\
\hline & & Air quality & $+(+)$ & Forest \\
\hline & & Water filtration & ++ & Agriculture (forest?) \\
\hline & & Nutrient sequestration & $+(+)$ & Agriculture (forest?) \\
\hline & & Noise regulation & + & Forest \\
\hline & \multirow{2}{*}{$\begin{array}{l}\text { Regulation of } \\
\text { masses and } \\
\text { liquid flows }\end{array}$} & Erosion regulation & ++ & Agriculture \\
\hline & & Flood management & ++ & Agriculture (forest?) \\
\hline & \multirow{5}{*}{$\begin{array}{l}\text { Maintenance of } \\
\text { physical, } \\
\text { chemical and } \\
\text { biological } \\
\text { conditions }\end{array}$} & Pollination & + & Forest/agriculture \\
\hline & & Growth environments & ++ & Water \\
\hline & & Soil quality & ++ & Agriculture \\
\hline & & Nitrogen sequestration & ++ & Agriculture \\
\hline & & Climate regulation & +++ & Forest/agriculture \\
\hline \multirow{6}{*}{$\begin{array}{l}\text { Cultural } \\
\text { services }\end{array}$} & \multirow{6}{*}{$\begin{array}{l}\text { Physical and } \\
\text { spiritual } \\
\text { interaction } \\
\text { with nature }\end{array}$} & Recreation & + & Forest/agriculture/water \\
\hline & & Nature tourism & $+(+)$ & Forest/agriculture/water \\
\hline & & Science and education & + & Forest/agriculture/water \\
\hline & & Natural heritage & ++ & Agriculture \\
\hline & & Landscape & + & Agriculture \\
\hline & & Art and popular culture & + & Agriculture \\
\hline
\end{tabular}




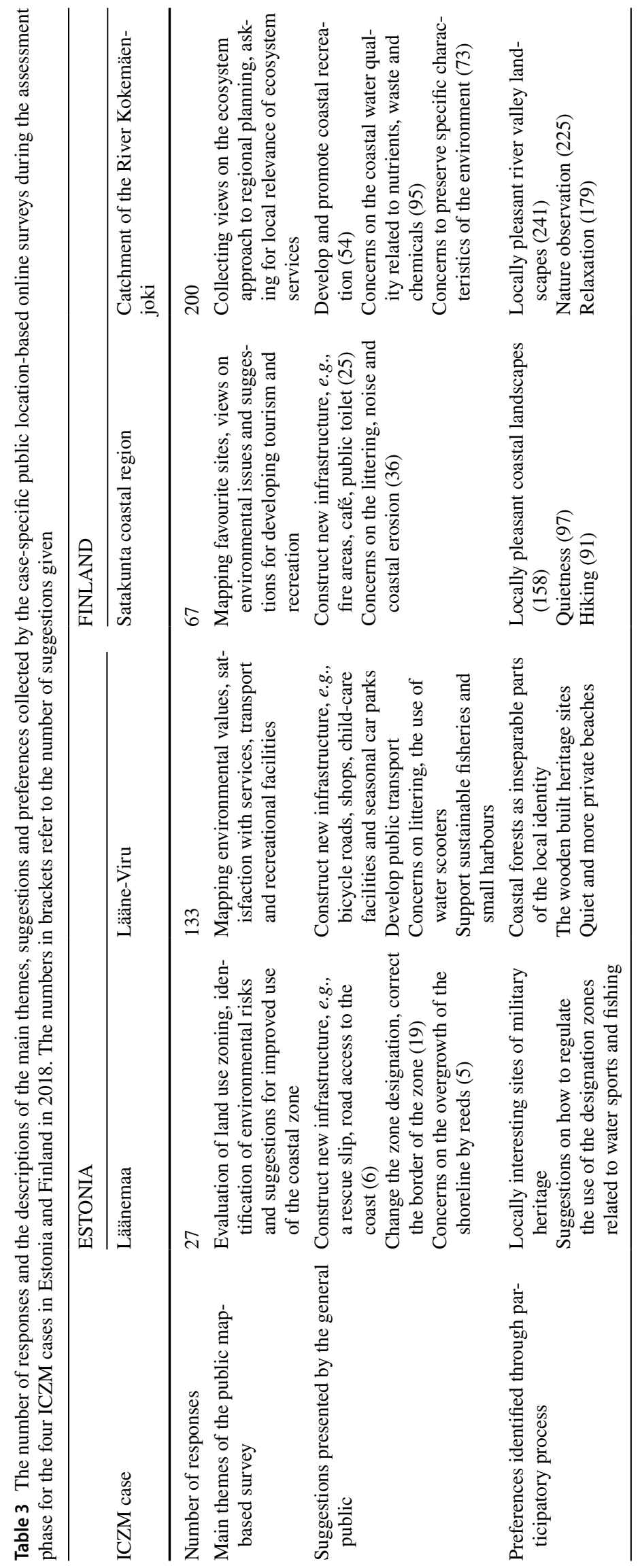


Acknowledgements The authors wish to express their gratitude to the members of the steering group, local and regional stakeholders and residents for sharing their knowledge during the preparation of the ICZM plans in Läänemaa and Lääne-Viru in Estonia and the Satakunta region in Finland.

Funding Open access funding provided by University of Turku (UTU) including Turku University Central Hospital. This work was funded by the Interreg Central Baltic Programme 2014-2020, European Regional Development Fund (CB354 SustainBaltic), and the Interreg Baltic Sea Region Programme (R098 Land-Sea-Act).

\section{Declarations}

Disclosure statement The authors declare that they have no conflicts of interest.

Open Access This article is licensed under a Creative Commons Attribution 4.0 International License, which permits use, sharing, adaptation, distribution and reproduction in any medium or format, as long as you give appropriate credit to the original author(s) and the source, provide a link to the Creative Commons licence, and indicate if changes were made. The images or other third party material in this article are included in the article's Creative Commons licence, unless indicated otherwise in a credit line to the material. If material is not included in the article's Creative Commons licence and your intended use is not permitted by statutory regulation or exceeds the permitted use, you will need to obtain permission directly from the copyright holder. To view a copy of this licence, visit http://creativecommons.org/licenses/by/4.0/.

\section{References}

Ballinger R, Pickaver A, Lymbery G, Ferreria M (2010) An evaluation of the implementation of the European ICZM principles. Ocean Coast Manag. https://doi.org/10.1016/j.ocecoaman.2010.10.013

CBD (2004) The Ecosystem Approach, CBD Guidelines. The Secretariat of the Convention on Biological Diversity (CBD), Montreal. https://www.cbd.int/convention/. Accessed 2 Dec 2018

Cisin-Sain B (1993) Sustainable development and integrated coastal management. Ocean Coast Manag 21:11-43

Collins K, Ison R (2009) Jumping off Arnstein's ladder: social learning as a new policy paradigm for climate change adaptation. Policy Gov Environ. https://doi.org/10.1002/eet.523

Costanza R (1999) The ecological, economic, and social importance of the oceans. Ecol Econ. https://doi.org/10.1016/S0921-8009(99) 00079-8

Earth Summit (1992) Agenda 21 - the United Nations Programme of Action from Rio. CreateSpace - Independent Publishing Platform. https://sustainabledevelopment.un.org/outcomedocuments/agend a21. Accessed 24 Nov 2018

EC (2002) Council recommendation of the European Parliament and of the Council of 30 May concerning the implementation of Integrated Coastal Zone Management in Europe (2002/413/EC) European Commission (EC), Brussels L 148/24

EC (2014a) Innovation in the blue economy: realizing the potential of our seas and oceans for jobs and growth. Communication $\operatorname{COM}(2014) 254$ final/2 to the European economic and social committee and the committee of the regions. European Commission (EC), Brussels

EC (2014b) Directive 2014/89/EU of the European Parliament and of the Council establishing a framework for maritime spatial planning. European Commission (EC). Official journal of the European Union L 257/135, Brussels

EC (2018a) Cross-border consultation on maritime spatial plans. Final Technical Study. Executive agency for small and medium-sized enterprises (EASME). European Commission (EC), Brussels

EC (2018b) Policy Brief - Implementing the Ecosystem-Based Approach in Maritime Spatial Planning. Version: 25 October, 2018. European MSP Platform. https://www.msp-platform.eu/ sites/default/files/20181025_ebainmsp_policybrief_mspplatform. pdf. Accessed 4 April 2021

Estonian Government (2017) Üleriigilise planeeringu Eesti mereala ja sellega piirneva rannikuala, samuti majandusvööndi teemaplaneeringu ja keskkonnamõju strateegilise hindamise algatamine [Initiation of a national plan for the Estonian marine area and the adjacent coastal area, as well as the strategic planning and the environmental impact assessment] In Estonian https://www.riigi teataja.ee/akt/330052017003. Accessed 12 Oct 2018

Estonian Ministry of the Interior (2013) National Spatial Plan Estonia 2030+. https://eesti2030.files.wordpress.com/2014/02/estonia2030.pdf. Accessed 30 Nov 2018

Estonian Planning Act (2015) https://www.riigiteataja.ee/en/eli/ee/Riigi kogu/act/513072018002/consolide Accessed 15 Oct 2018

Finnish Land Use and Building Act (1999) Entry into force 5.2.1999/132. https://www.finlex.fi/fi/laki/ajantasa/1999/19990 132. Accessed 1 Nov 2018

Forst MF (2009) The convergence of Integrated Coastal Zone Management and the ecosystems approach. Ocean Coast Manag. https:// doi.org/10.1016/j.ocecoaman.2009.03.007

Gillgren C, Støttrup JG, Schumacher J, Dinesen GE (2018) Working together: collaborative decision making for sustainable integrated coastal management (ICM). J Coast Conserv. https://doi.org/10. 1007/s11852-018-0631-z

HELCOM (1994) Recommendation 15/1. Protection of the coastal strip. Helsinki Commission (HELCOM). http://www.helcom.fi/Recom mendations/Rec\%2015-1.pdf. Accessed 20 Dec 2019

Hendrikson and Ko OÜ (2018) Mereala ruumilise planeerimise metoodika. Töögrup: Kuusik M Siseministeerium; Metspalu P, Kartau K, Peet K Hendrikson \& Ko OÜ; Martin G TÜ Eesti Mereinstituut. Töö nr 1308/09 [Methods for the Maritime Spatial Planning] In Estonian https://issuu.com/hendrikson/docs/merea lade_planeerimise_metoodika/2. Accessed 5 Dec 2018

Ijäs A (2018a) Developing sustainable tourism in Satakunta's coastal zone - from the perspective of land use planning. The ICZM of Satakunta coastal region. Regional Council of Satakunta. https:// sites.utu.fi/sustainbaltic/. Accessed 12 Jan 2019

Ijäs A (2018b) Integrating the ecosystem services of the Kokemäenjoki river valley into land use planning. The ICZM of the river valley of Kokemäenjoki. Regional Council of Satakunta. https://sites.utu.fi/ sustainbaltic/. Accessed 12 Jan 2019

Inàcio M, Schernewski G, Nazemtseva Y, Baltranaitè E, Friedland R, Benz J (2018) Ecosystem services provision today and in the past: a comparative study in two Baltic lagoons. Ecol Res. https://doi. org/10.1007/s11284-018-1643-8

Kaituri A, Vatanen S, Yrjölä R, Pakkanen T, Hannula H, Saarniaho K, Uusitalo T (2017) Premises of marine spatial planning. Current use of marine areas, future prospects and knowledge base concerning marine areas. Reports of the Ministry of the Environment 
15/2017. http://urn.fi/URN:ISBN:978-952-11-4708-1. Accessed 20 Nov 2018

Kerr S, Johnson K, Side JC (2016) Planning at the edge: Integrating across the land sea divide. Mar Policy. https://doi.org/10.1016/j. marpol.2014.01.023

Kull A, Palginõmm V, Semm M, Tomson P (2018) Spatial development plan for the coastal area between Hara Peninsula and Ristinina. ICZM plan for the Läänemaa case area. https://sites.utu.fi/susta inbaltic/. Accessed 12 Jan 2019

Külm S, Raet J, Kull A, Sepp K, Tomson P, Semm M, Printsmann A, Pikner T (2017) High Nature and Cultural Heritage Values with the Challenge of Marginalisation. https://blogit.utu.fi/sustainbal tic/2017/11/29/the-first-results-on-the-human-ecological-dataintegration/. Accessed 21 Jan 2019

Kuusik M, Pikner T, Printsmann A, Raet J (2018) Lääne-Viru integrated coastal zone management plan. https://sites.utu.fi/susta inbaltic/. Accessed 12 Jan 2019

Laurila L, Kalliola R (2008) Rakennetut meren rannat [Built-up shorelines] 2005. Reports of the Ministry of the Environment 3/2008. Ministry of the Environment, Land Use Department. Edita Prima Ltd, Helsinki

Leikola N, Kiviluoto S, Nurmi M, Syrjänen K, Kostamo K, Mononen L, Vihervaara P (2018) Työraportti SustainBaltic hankkeen vaiheesta A.T1.1 Integrating obtainable environmental and human activity data into planning processes by GIS analysis tools [Working report on the SustainBaltic project phase of A.T1.1] In Finnish https://sites.utu.fi/sustainbaltic/etusivu/project-implementationand-deliverables/. Accessed 21 Jan 2019

Louekari S (2012) Maatalousmaiseman muotoutuminen Porin seudulla 1700-1900 [Agricultural landscape changes 1700-1900 in Pori region. In: Uusi-Seppä N (ed) Cultural environments of Satakunta past, present, future] In Finnish Satakunnan Museon julkaisuja 19/2012: pp 46-55

Mononen L, Auvinen A-P, Ahokumpu A-L, Rönkä M, Aarras N, Tolvanen H, Kamppinen M, Viirret E, Kumpula T, Vihervaara P (2015) National ecosystem service indicators: Measures of socio-ecological sustainability. Ecol Indic 61(1):27-37

Niemelä J, Saarela S-R, Söderman T, Kopperoinen L, Yli-Pelkonen V, Väre S, Kotze J (2010) Using the ecosystem services approach for better planning and conservation of urban green spaces: a Finland case study. Biodivers Conserv. https://doi.org/10.1007/ s10531-010-9888-8

Nummela A, Pohja-Mykrä M, Ijäs A, Perttula E, Roslöf S, Savola A, Juvonen T, Lusenius H, Salminen P, Jutila H, Lindberg W (2019) Merialuesuunnittelu. Saaristomeren ja Selkämeren eteläosan suunnittelualueen ominaispiirteet 1.4.2019. [Maritime Spatial Planning. The characteristics of the planning area in the Archipelago Sea and the southern Bothnian Sea] In Finnish https://www.merialuesuunnittelu.fi/wp-content/uploads/2019/12/ Nummela-A.-et-al.-2019.-Merialuesuunnittelu---Saaristomerenja-Selkämeren-eteläosan-suunnittelualueen-ominaispiirteet.pdf. Accessed 20 Dec 2019

Palginõmm V, Veersalu T (2013) Kuidas planeerida rannikuid - Saare makonna rannaala tsoneering. Peatükke planeerimisest: protsesse, meetodeid ja näiteid [How to plan the coasts - Zoning of the coastal area of Saare County. In: Roose A (ed) Chapters on planning: processes, methods, and examples]. Tartu, Estonia. In Estonian pp 246-262

Papageorgiou M (2016) Coastal and marine tourism: A challenge factor in Marine Spatial Planning. Ocean Coast Manag. https://doi.org/ 10.1016/j.ocecoaman.2016.05.006

Pomeroy R, Douvere F (2008) The engagement of stakeholders in the marine spatial planning process. Mar Policy. https://doi.org/10. 1016/j.marpol.2008.03.017
Printsmann A, Pikner T (2019) The role of culture in the self-organisation of coastal fishers sustaining coastal landscapes: a case study in Estonia. Sustainability. https://doi.org/10.3390/su11143951

Regional Council of Satakunta (2017) Satakunnan maakuntaohjelma 2018-2021 [The Regional Programme of Satakunta 2018-2021] Satakuntaliitto, Pori. In Finnish http://www.satakuntaliitto.fi/sites/ satakuntaliitto.fi/files/tiedostot/Aluekehitys/MAKO_2018_2021/ Satakunnan_maakuntaohjelma_2018-2021_SahkoinenJulkaisu_ LowRes.pdf. Accessed 1 Feb 2020

Rinne J, Primmer E (2016) A case study of ecosystem services in Urban Planning in Finland: benefits rights and responsibilities. J Environ Pol Plan. https://doi.org/10.1080/1523908X.2015.10767 21

Schaefer N, Barale V (2011) Maritime spatial planning: opportunities \& challenges in the framework of the EU integrated maritime policy. J Coast Conserv. https://doi.org/10.1007/s11852-011-0154-3

Schernewski G, Schumacher J, Weisner E, Donges L (2018) A combined coastal protection, realignment and wetland restoration scheme in the southern Baltic: planning process, public information and participation. J Coast Conserv. https://doi.org/10.1007/ s11852-017-0542-4

Similä J, Borgström S, Kopperoinen L, Itkonen P, Auvinen A-P, Koivulehto M (2017) Dependence of ecosystem services and biodiversity on green infrastructure and changes needed in the regulation. Reports of the Ministry of the Environment 17/2017

Slocombe DS (1993) Implementing ecosystem-based management. Bioscience. https://doi.org/10.2307/1312148

Small C, Nicholls RJ (2003) A global analysis of human settlements in coastal zones. J Coastal Res. https://www.jstor.org/stable/4299200

Soininen N (2015) Marine spatial planning in the European Union. In: Hassan D, Kuokkanen T, Soininen N (eds) Transboundary Marine Spatial Planning and International Law. Taylor \& Francis Group, London and New York, pp 189-201

Sorensen J (1993) The international proliferation of integrated coastal zone management efforts. Ocean Coast Manag 53:45-80

Stojanovic TA, Farmer CJQ (2013) The development of world oceans $\&$ coasts and concepts of sustainability. Mar Policy. https://doi. org/10.1016/j.marpol.2013.02.005

Støttrup JG, Dinesen GE, Janßen H, Gillgren C, Schernewski G (2017) Re-visiting ICM theory and practice: lessons learned from the Baltic Sea Region. Ocean Coast Manag. https://doi.org/10.1016/j. ocecoaman.2017.02.002

Støttrup JG, Dinesen GE, Schumacher J, Gillgren C, Inácio M, Schernewski G (2019) The systems approach framework for collaborative, science-based management of complex systems. J Coast Conserv. https://doi.org/10.1007/s11852-018-00677-5

Tafon R, Howarth D, Griggs S (2018) The politics of Estonia's offshore wind energy programme: Discourse, power and marine spatial planning. Environ Plann C: Politics Space. https://doi.org/10. $1177 / 2399654418778037$

Tammi I, Mustajärvi K, Rasinmäki J (2017) Integrating spatial valuation of ecosystem services into regional planning and development. Ecosyst Serv. https://doi.org/10.1016/j.ecoser.2016.11.008

Tritter JQ, McCallum A (2006) The snakes and ladders of user involvement: moving beyond Arnstein. Health Policy. https://doi.org/10. 1016/j.healthpol.2005.05.008

UNEP (United Nations Environment Programme) (2009) Sustainable Coastal tourism - An integrated planning and management approach http://www.greentrek.org/files/2013/09/SustainableCoas talTourism-PlanningUNEP.pdf. Accessed 12 March 2018

UNEP (United Nations Environment Programme), UNWTO (The World Tourism Organization) (2005) Making tourism more sustainable - A guide for policy makers https://www.sustainablesids. org/knowledgebase/unep-wto-making-tourism-more-sustainablea-guide-for-policy-makers-2005. Accessed 12 March 2018 
Väinameri Project (2005) Linking rural life and coastal nature. Arhipelaag. https://www.wwf.se/source.php/1119653/Vainameri_report_ book.pdf. Accessed 14 Oct 2018

Valner S (ed) (2018) Haldusreform 2017. Artiklikogumik: otsused, taustad, elluviimine [Administrative reform 2017. Article collection: decisions, backgrounds, implementation]. Estonian Ministry of Finance, Tallinn. In Estonian https://www.rahandusministe erium.ee/sites/default/files/Haldusreform\%202017.pdf. Accessed 28 Nov 2018
Vilen R (2019) Satakunnan maakuntakaavassa osoitettujen suojelualueiden nykytilan arviointi [The present characteristics of the protected areas in the Satakunta regional plan] Regional Council of Satakunta, Pori. In Finnish http://www.satakuntaliitto.fi/luont oselvitys2019. Accessed 21 Jan 2020

Publisher's note Springer Nature remains neutral with regard to jurisdictional claims in published maps and institutional affiliations. 